\title{
Sistem Informasi Kependudukan Pada Kantor Lurah Sangaji Berbasis Web
}

\author{
Moch. Teguh Priyangto ${ }^{1}$, Abjan Samad ${ }^{2}$, Sitna Hajar Hadad ${ }^{3}$ \\ Program Studi Manajemen Informatika ${ }^{1}$, Program Studi Teknik Komputer ${ }^{2,3}$ \\ Akademi Ilmu Komputer (AIKOM) Ternate \\ muhammadteguhpry@gmail.com
}

\begin{abstract}
Abstrak
Sistem informasi penduduk dimaksud untuk meningkatkan efisiensi dalam hal pelayanan dalam masyarakat. Kelurahan Sangaji kota ternate utara selama ini mempunyai sistem informasi yang masih dalam bentuk manual sehingga menyulitkan dan memperlambat dalam proses penambahan, penghapusan (atau pembuatan surat). Oleh sebab itu perlu dilakukan penelitian untuk merancang aplikasi sistem informasi penduduk. Tujuan dari sistem informasi ini adalah untuk memberikan kemudahan kepada masyarakat dalam melakukan pengurusan dokumen kelurahan, serta menginformasikan pelayanan masyarakat yang efisiensi. Langkahlangkah yang dilakukan dalam hal ini adalah analisis kebutuhan sistem, perancangan sistem. Dalam implementasi ini digunakan bahasa pemograman $P H P$ dan sebagai databasenya digunakan $M y S Q L$.
\end{abstract}

Kata Kunci: Sistem Informasi, Kependudukan, PHP, Database, MySQL.

\section{Abstract}

The population information system is intended to improve efficiency in terms of service in the community. Sangaji Urban Village North Ternate City has an information system that is still in the manual form which makes it difficult and slow in the process of adding, deleting (or making letters). Therefore it is necessary to do research to design a population information system application. The purpose of this information system is to provide convenience to the community in managing urban village documents, as well as providing efficient public services. The steps taken in this case are system requirements analysis, system design. In this implementation, the PHP programming language is used and the database is used by MYSQL.

Keywords: Information Systems, Population, PHP, Database, MySQL

\section{PENDAHULUAN}

Pada era teknologi seperti sekarang ini sebuah website berupa system informasi dapat memberikan pengaruh yang cukup besar terhadap suatu instansi pemerintahan maupun perusahaan, dengan adanya sebuah system informasi ini dapat membantu dalam pengurusan surat-surat keluaran di suatu instansi pemerintahan khususnya dalam bidang kependudukan pada kantor lurah kelurahan Sangaji.

Kelurahan merupakan pembagian wilayah administratif di Indonesia di bawah kecamatan, mengingat jumlah penduduk di kelurahan yang begitu banyak yang akan memperlambat kinerja petugas dalam mengurus surat-surat keluaran yang di minta oleh masyarakat.

Dengan adanya permasalahan tersebut maka penulis membuat suatu aplikasi yaitu "Aplikasi Sistem Informasi Kependudukan Pada Kantor Lurah Sangaji" system tersebut diharapkan dapat membantu petugas kelurahan sehingga dapat memberikan kemudahan pelayanan terhadap masyarakat

\section{Rumusan Masalah}


1. Bagaimana merancang Sistem Informasi Kependudukan Berbasis Web pada Kantor Lurah Sangaji dengan mengunakan pemograman framework PHP codigniter

2. Apakah aplikasi ini dapat berguna bagi masyarakat dalam mengurus suratsurat keluaran dari kelurahan

\section{Tujuan Penelitian}

Aplikasi ini diharapkan mampu mengatasi permasalahan-permasalahan yang ada di kelurahan.

\section{Manfaat Penelitian}

1. Dapat memberikan kemudahan kepada petugas dalam menghadapi masalah-masalh yang ada di kelurahan

2. Dengan adanya aplikasi ini dapat mempercepat masyarakat dalam proses pembuatan surat keluaran dari kelurahan

\section{Tinjauan Pustaka}

Didik Setiawan, Yhoni Agus Setya Mahendra Tahun (2015) melakukan penilitian dengan judul "Perancangan Sistem Informasi Penduduk Pada Kantor Desa Kebonsari". sistem ini akan membantu pendataan penduduk disuatu desa terutama pada proses pendataan Kartu Tanda Penduduk (KTP), Kartu Keluarga (KK), Surat Kelahiran, Surat Kematian, dan Surat Keterangan Pindah yang memerlukan kecermatan dan ketelitian tinggi

Ali Ibrahim, Ahmad Rifai, Lina Oktarina Tahun (2016) melakukan penilitian dengan judul " Ranang Bangun Aplikasi Pencatatan Data Kependudukan Kleurahan Pahlawan Berbasis Web". sistem ini dibuat untuk mempermudah pegawai dalam menjalankan tugas sebagai mengelola ataupun pencatatan kependuduka dan pelayanan public

Muhammad Agus Suripto, Ramadian Agus Triyono Tahun (2014) melakukan penilitian dengan judul "Pembangunan Sistem Informasi Akta Kelahiran Dinas Kependudukan Dan Pencatatan Sipil Sragen". sistem ini berguna dalam proses manajeman data kelahiran.

Syarif Hidayatulloh, Cisde Mulyadi Tahun 2015 melakukan penilitian dengan judul "Sistem Pelayanan Administrasi Kependudukan Desa Candigatak Berbasis Web". Sistem Informasi tersebut dapat meminimalisir resiko kesalahan penulisan identitas, mengolah mutasi kependudukan, dan dapat menampilkan arsip berbagai surat yang pernah diproses

\section{LANDASAN TEORI \\ Pengertian Sistem}

Menurut Mulyadi (2014:2), "Sistem adalah sekelompok unsur yang erat hubungannya satu dengan yang lainnya, yang berfungsi bersama-sama untuk mencapai tujuan tertentu

\section{Definisi Informasi}

Jeperson Hutahaean (2014) Informasi adalah data yang diolah menjadi bentukyang lebih berguna dan lebih berarti bagi penerimanya.Sumber informasi adalah data. Data kenyataan yangmenggambarkan suatu kejadiankejadian dan kesatuannyata. Kejadiankejadian (event) adalah kejadian yangterjadi pada saat tertentu

\section{Konsep Dasar Sistem Informasi}

Jeperson Hutahaean (2014) Sistem informasi adalah suatu sistem didalam suatuorganisasi yang mempertemukan kebutuhan pengelolaantransaksi harian, mendukung operasi, bersifat 
manajerial,dan kegiatan strategi dari suatu organisasi danmenyediakan pihak luar tertentu dengan laporan-laporanyang dibutuhkan

\section{Kependudukan}

Penduduk merupakan semua orang yang berdomosili di wilayah geografis Republik Indonesia selama 6 bulan atau lebih dan mereka yang berdomisili kurang dari 6 bulan dengan tujuan untuk menetap (BPS, 2014 : 102)

Pertumbuhan penduduk merupakan keseimbangan yang dinamis antara kekuatan-kekuatan yang menambah dan kekuatan yang mengurangi jumlah penduduk. Pertumbuhan penduduk diakibatkan oleh empat komponen yaitu : kelahiran (fertilitas), kematian (mortalitas), migrasi masuk, dan migrasi keluar (Subri,2003:16).

\section{Kelurahan}

Kelurahan adalah pembagian wilayah administratif di Indonesia di bawah kecamatan. Kelurahan merupakan wilayah kerja lurah sebagai perangkat daerah kabupaten atau kota. Kelurahan dipimpin oleh seorang lurah yang berstatus sebagai Pegawai Negeri Sipil. Kelurahan merupakan unit pemerintahan terkecil setingkat dengan desa. Berbeda dengan desa, kelurahan memiliki hak mengatur wilayahnya lebih terbatas. Dalam perkembangannya, sebuah desa dapat diubah statusnya menjadi kelurahan, atau sebaliknya.

\section{Website}

Menurut Bekti (2015:35) Website merupakan kumpulan halaman-halaman yang digunakan untuk menampilkan informasi teks, gambar diam atau gerak, animasi, suara, dan atau gabungan dari semuanya, baik yang bersifat statis maupun dinamis yang membentuk satu rangkaian bangunan yang saling terkait, yang masing-masing dihubungkan dengan jaringan-jaringan halaman.

\section{Pengertian CodeInigter}

Menurut Hakim (2010:8) CodeIgniter adalah sebuah framework PHP yang dapat membantu mempercepat developer dalam pengembangan aplikasi web berbasis $P H P$ dibanding jika menulis semua kode program dari awal

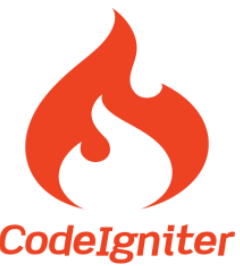

Gambar 1. Logo CodeIgniter

Sumber: Hakim (2010:9) Membangun Web Berbasis PHP dengan Framework CodeIgniter

$U M L$

Menurut Rosa dan Shalahuddin (2014:133), berpendapat bahwa $U M L$ (Unified Modeling Language) adalah "Salah standar bahasa yang banyak digunakan di dunia industri untuk mendefinisikan requerement, membuat analisa \& desain, serta menggambarkan arsitektur dalam pemrograman berorintasi objek". Sedangkan Mulyani (2016:48) mengatakan UML (Unified Modeling Language) adalah "Sebuah teknik pengembangan sistem yang menggunakan bahasa grafis sebagai alat untuk pendokumentasian dan melakukan spesifikasi pada sistem".

\section{METODE PENELITIAN}

Pada Penilitian ini akan dibangun sebuah perangakat lunak yang diberi nama SiPKes sesuai dengan alamat untuk mengakses aplikasi tersebut via web yaitu 
SiPKes.com. SiPKes adalah singkatan dari Sistem Informasi Penduduk Kelurahan Sangaji. pada Gambar 2 diagram alir, yaitu studi literatur dan kajian pustaka identifikasi permasalahan, perancangan, implementasi, dan analisis hasil penelitian.

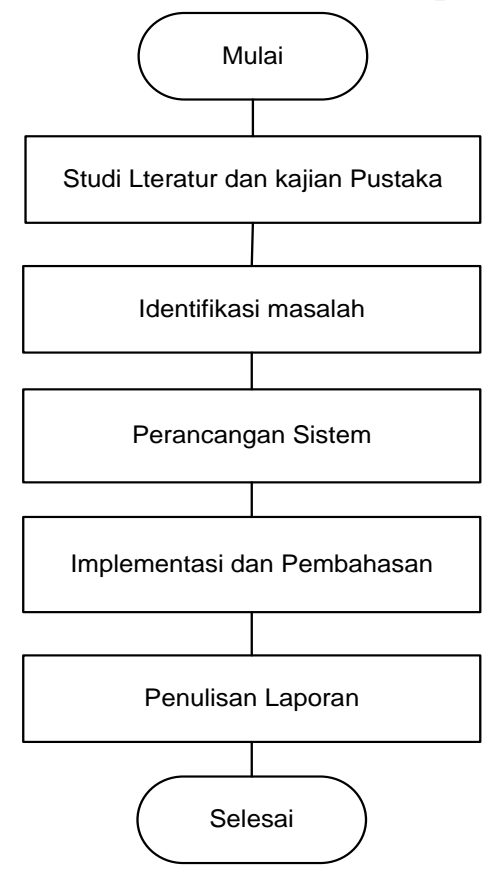

Gambar 2. Diagram Alir

\section{Studi Literatur dan Kajian Pustaka}

Tahapan ini di lakukan untuk mendapatkan beberapa referensi atau litelatur yang terkait dalam penelitian ini sebagai pembelajaran teori yang akan diteliti.

\section{Identifikasi Masalah}

Tahapan ini dilakukan proses pengidentifikasian masalah yang akan di selesaikan dalam penelitian ini, setelah masalah di rumuskan langka selanjutnya adalah menetukan tujuan dari penelitian yang merupakan sasaran yang nantinya akan di wujudkan dari penyelesaian permasalahan yang akan di teliti.

\section{Perancangan Sistem}

Tahap ini merupakan tahapan dalam merancang suatu system informasi yang sesuai dengan analisis kebutuhan pengguna dan kebutuhan system.

\section{Implementasi Dan Pembahasan}

Tahapan ini merupakan hasil dari analisis yang telah di lakukan dengan mengimplementasikan hasil perancangan system

\begin{abstract}
Alat
Kelengkapan alat yang di gunakan untuk mendukung penelitian ini di bagi ke dalam dua bagian yaitu perangkat keras (Hardware) dan perangkat lunak (Software). Berikut ini merupakan pembagiannya.
\end{abstract}

\section{Bahan}

Bahan penelitian yang di gunakan dalam penelitian ini yaitu data hasil pengamatan langsung, maksud pengamatan tersebut di lakukan melalui literatur-literature seperti jurnal dan buku.

\section{Detail Spesifikasi Hardware}

Detail spesifikasi Hardware digunakan untuk membangun sistem agar dapat berjalan dengan baik. Spesifikasi hardware dan platform yang digunakan dalam pembangunan aplikasi yang diberi nama SiPkes.com adalah sebagai berikut:

Tabel 1. Spesifikasi Hardware

\begin{tabular}{|l|l|}
\hline \multicolumn{1}{|c|}{ Jenis } & \multicolumn{1}{c|}{ Spesifikasi yang di gunakan } \\
\hline Processor & $\begin{array}{l}\text { Intel(R) Pentium(R) CPU N3540 } \\
\text { @ } 2.16 \mathrm{GHz} 2.16 \mathrm{GHz}\end{array}$ \\
\hline Memori & $2.00 \mathrm{~GB} . \mathrm{RAM}$ \\
\hline Harddisk & $500 \mathrm{~GB}$ \\
\hline I/O & Monitor, Keyboard, Mouse \\
\hline
\end{tabular}

\section{Detail Spesifikasi Software}

Spesifikasi perangkat lunak yang akan digunakan untuk membangun sistem SiPkes.com yaitu : 
Tabel 2. Spesifikasi Software

\begin{tabular}{|c|c|}
\hline Jenis & Tipe \\
\hline $\begin{array}{c}\text { Bahasa } \\
\text { Pemrograman atau } \\
\text { sejenisnya }\end{array}$ & HTML 5, Code Igniter \\
\cline { 2 - 2 } & PHP \\
\hline Web Server & MySQL Friends XAMPP \\
\hline Database & MySQL \\
\hline Editor /IDE & Sublime text 3 \\
\hline $\begin{array}{l}\text { Plug-in dan } \\
\text { Pustaka }\end{array}$ & Browser \\
\hline
\end{tabular}

\section{ANALISIS DAN PERANCANGAN}

Tahapan ini penulis menggunakan pemodelan $U M L$ yang terdiri dari Use Case Diagram dan Activity Diagram yang dapat di lihat pada perancangan berikut ini.

\section{Use Case Diagram}

Dalam menganalisis suatu kebutuhan system, penulis menggunakan pemodelan use case diagram. berikut gambaran dari use case diagram system yang diusulkan pada user.

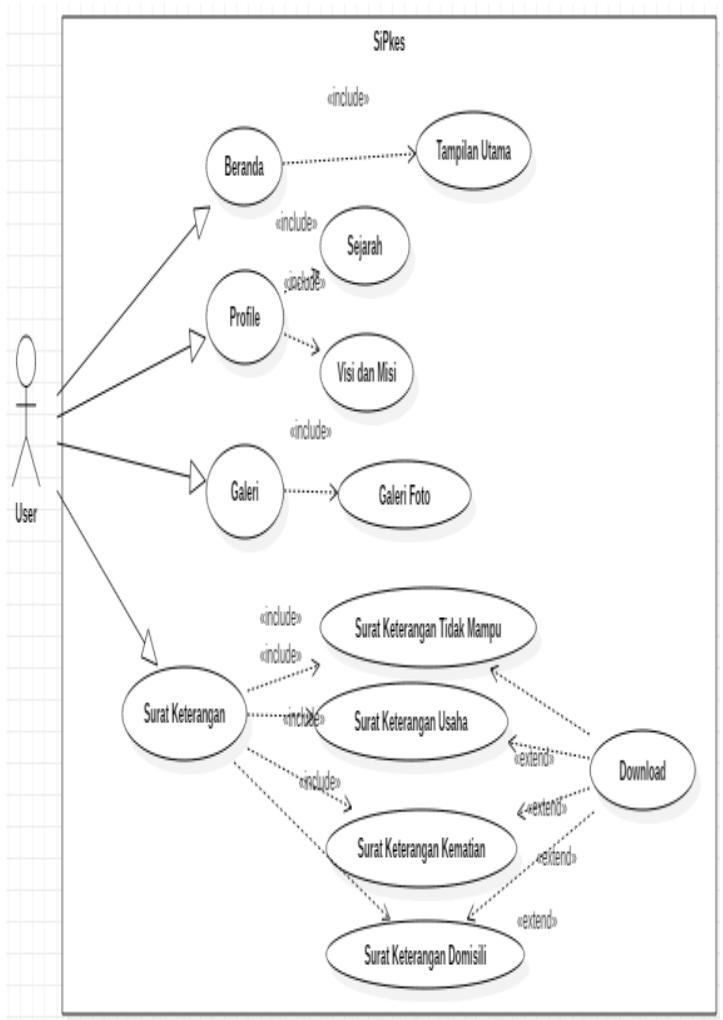

Gambar 3. Use Case Diagram User

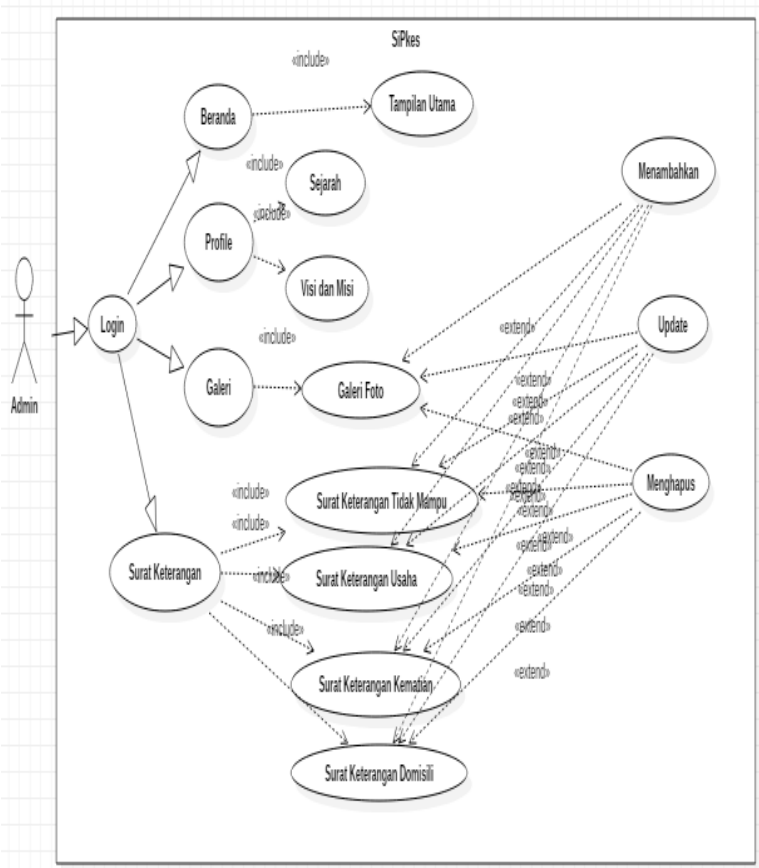

Gambar 4. Use Case Diagram Admin

\section{Activity Diagram}

Activity Diagram memgambarkan bagaimana alur aktivitas yang ada dalam sistem yang akan dibuat. Berikut adalah alur aktivitas diagram:

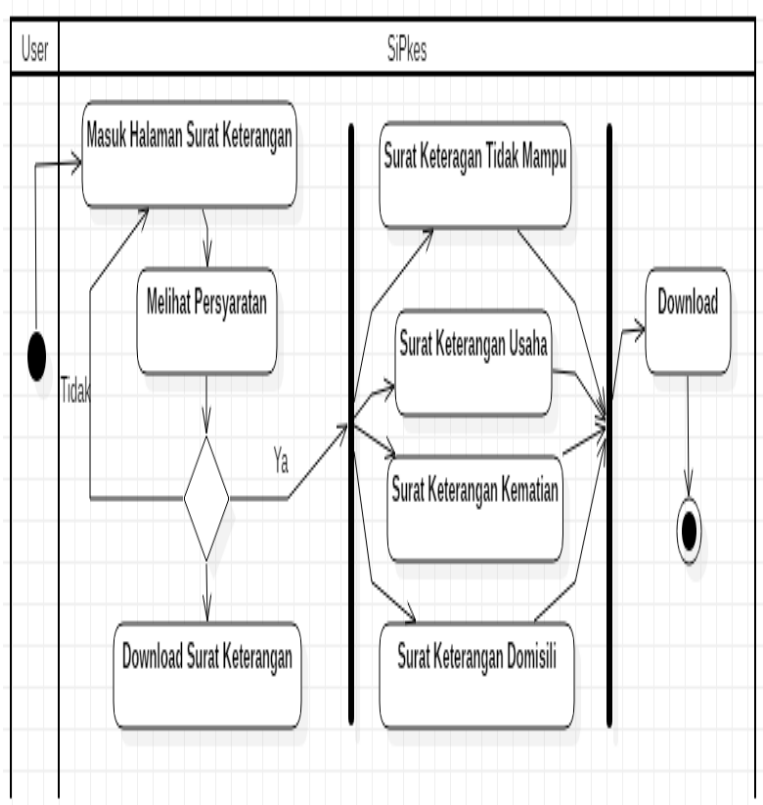

Gambar 5. Activity Diagram

\section{Struktur Table}

Tabel Admin

Fungsi Tabel : Menyimpan data admin 
Field Kunci Utama : id

Field Kunci Tamu : -

Jumlah Field : : 3

Tabel 3. Admin

\begin{tabular}{|l|l|c|}
\hline \multicolumn{1}{|c|}{ Field } & \multicolumn{1}{c|}{ Type } & Key \\
\hline Id & Int (15) & Primari key \\
& & \\
\hline Username & Varcar (20) & - \\
\hline Password & Varcar (50) & - \\
\hline
\end{tabular}

Tabel Kategori Surat keterangan

Fungsi Tabel : Menyimpan data

surat keterangan

Field Kunci Utama : id

Field Kunci tamu : -

Jumlah Field : : 3

Tabel 4. Surat Keterangan

\begin{tabular}{|l|l|c|}
\hline \multicolumn{1}{|c|}{ Field } & \multicolumn{1}{c|}{ Type } & Key \\
\hline Id & Int (20) & Primari key \\
\hline Nama & Varcar (30) & - \\
\hline File Name & Vercar (30) & - \\
\hline
\end{tabular}

Tabel Kategori Galeri

Fungsi Tabel : Menyimpan data galeri

Field Kunci Utama : id

Field Kunci tamu : :

Jumlah Field : : 3

Tabel 5. Galeri

\begin{tabular}{|l|l|c|}
\hline \multicolumn{1}{|c|}{ Field } & \multicolumn{1}{c|}{ Type } & Key \\
\hline Id & Int (20) & Primari key \\
\hline Nama & Varcar (30) & - \\
\hline File Gambar & Vercar (30) & - \\
\hline
\end{tabular}

\section{Rancangan Antarmuka}

Rancangan antarmuka merupakan desain awal dari sebuah system yang akan di bangun oleh penulis, dan berikut ini merupakan rancangan antar muka yang telah di buat.

Gambar di bawah ini adalah tampilan beranda dari aplikasi SiPKes.

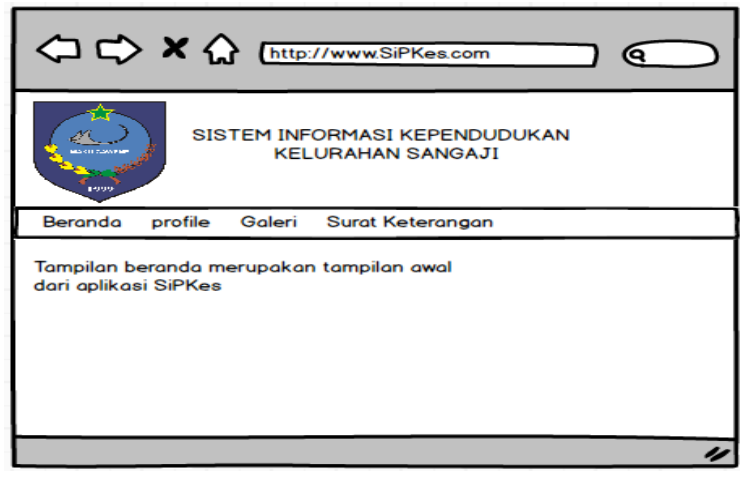

Gambar 6. Tampilan Beranda

Gambar dibawah adalah tampilan melihat Profile Kelurahan aplikasi SiPKes.

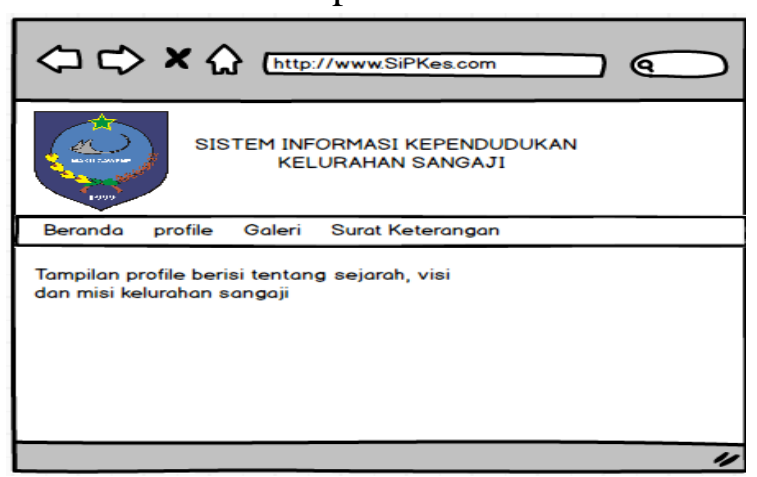

Gambar 7. Tampilan Profile

Gambar ini menampilkan Galeri dimana masyarakat dapat melihat Foto-foto dari kelurahan.

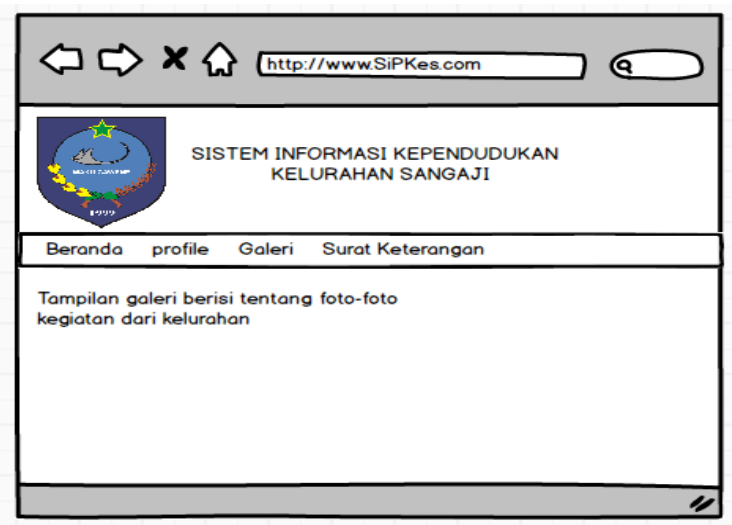

Gambar 8. Tampilan Galeri

Gambar dibawah ini adalah tampilan surat keterangan di mana berisi tentang informasi persyaratan surat keterangan dan

juga terdapat link surat keterangan yang dapat di download. 


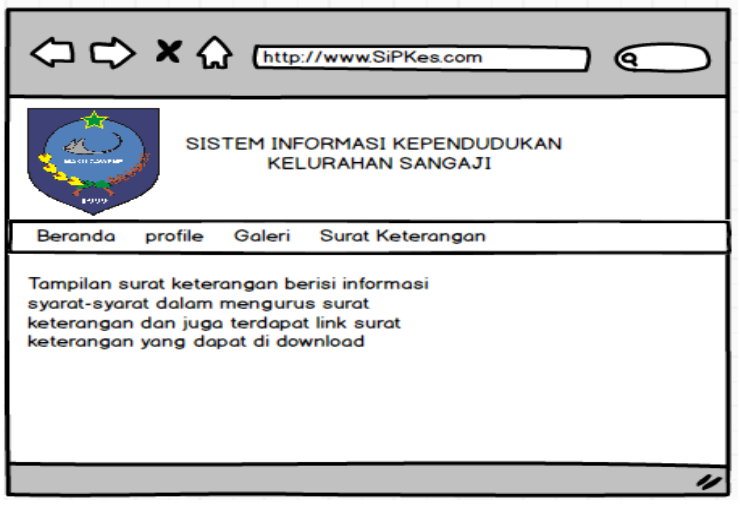

Gambar 9. Tampilan Surat Keterangan

\section{IMPLEMENTASI DAN PEMBAHASAN} Hasil Penelitian

Hasil penelitian ini merupakan langkah realisasi dari perancangan aplikasi. Setiap rancangan yang telah dibuat sebelumnya akan direalisasikan menggunakan bahasa pemrograman. Dalam perancangan Sistem Informasi Kependudukan Kelurahan sangaji, bahasa pemrograman yang digunakan adalah bahasa pemrograman PHP framework Codeigniter, HTML, dan CSS. Sedangkan untuk pengelolaan datanya menggunakan $M y S Q L$ dalam tool XAMPP.

\section{Implementasi}

Tahap ini merupakan hasil dari pembuatan aplikasi yang dapat di lihat pada gambar di bawah ini.

Tampilan ini merupakan tampilan utama saat masuk ke dalam aplikasi Sipkes.

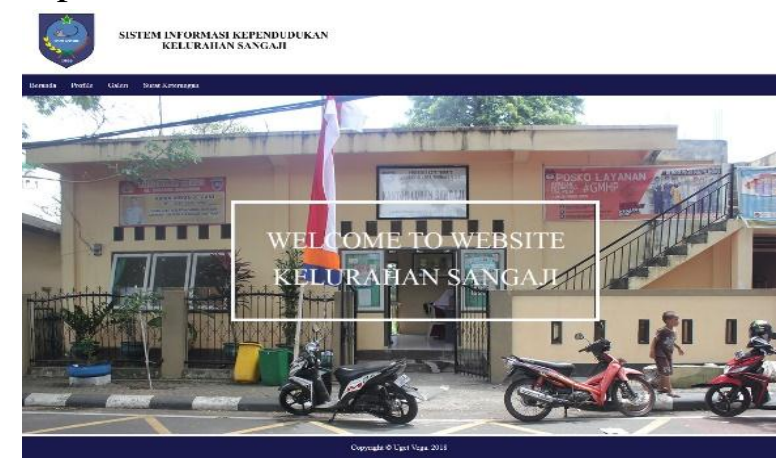

Gambar 10. Tampilan Beranda
Tampilan ini merupakan tampilan profil dari kelurahan sangaji, tampilan ini terdapat dua view yaitu view Sejarah dan Visi Misi dari kelurahan sangaji yang ada pada aplikasi Sipkes.

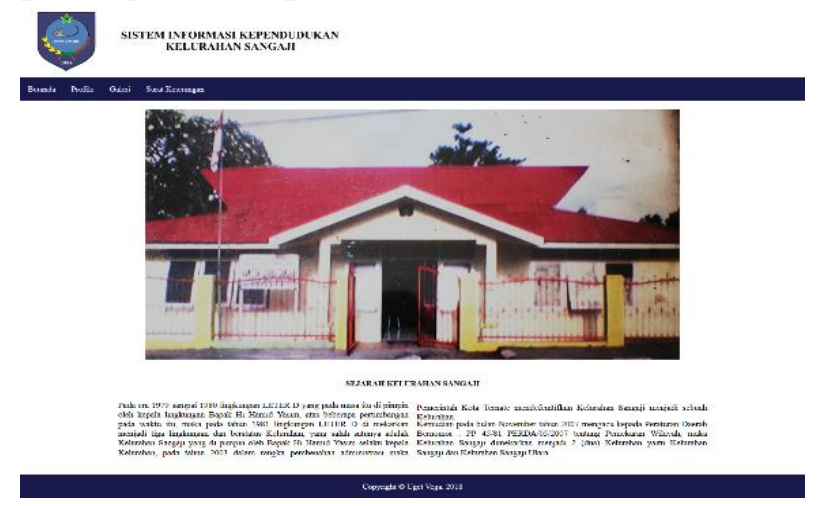

Gambar 11. Tampilan Sejarah

Tampilan visi misi dapat di lihat pada gambar di bawah ini :

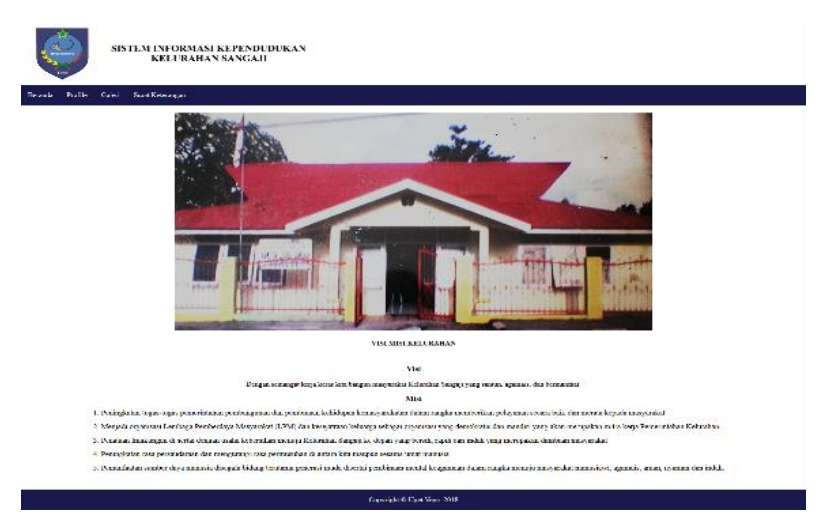

Gambar 12. Tampilan Visi Misi

Tampilan ini merupakan tampilan yang berisi foto-foto kegiatan dari kelurahan sangaji. Berikut adalah tampilan galeri foto dan listing program galeri foto.

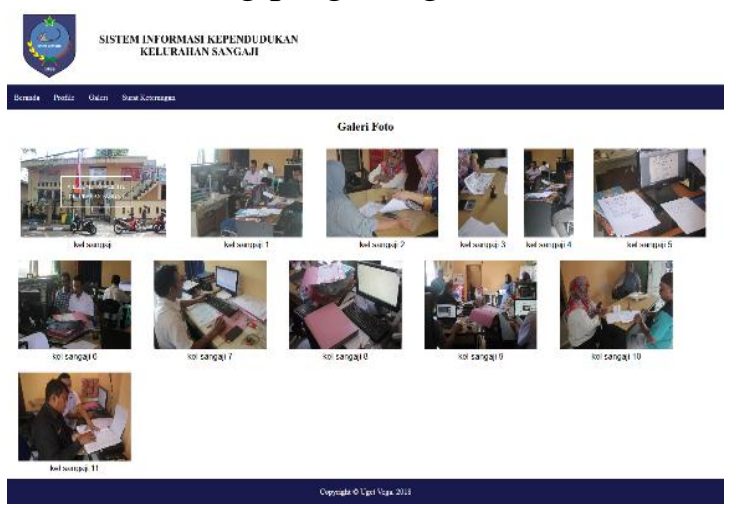

Gambar 13. Tampilan Galeri 
Tampilan ini merupakan tampilan yang berisi persyaratan-persyaratan dan file surat keterangan yang dapat di download oleh user.

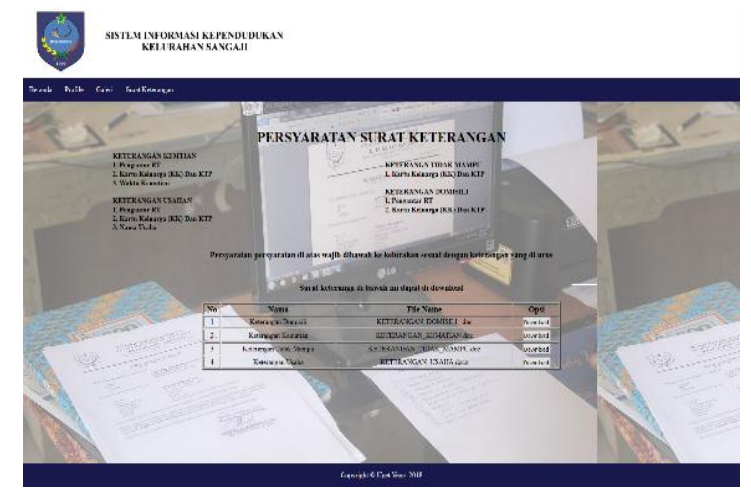

Gambar 14. Tampilan Surat Keterangan

\section{KESIMPULAN}

1. Dengan adanya aplikasi ini maka proses dalam pengurusan surat keterangan akan menjadi lebih mudah dan cepat, proses pengursan juga akan menjadi lebih cepat dan tepat

2. Proses yang cepat akan membuat masyarakat menjadi nyaman dalam pengurusan yang berhubungan dengan surat keterangan.

\section{Saran}

1. Diharapkan kedepannya aplikasi ini dapat di kembangkan oleh mahasiswa agar lebih lengkap

2. Untuk meningkatkan kualitas mahasiswa di harapkan dapat memanfaatkan aplikasi ini sebagai bahan pembelajaran dan pengembangan.

\section{DAFTAR PUSTAKA}

Hidayatulloh, Syarif., dan Mulyadi Cisde (2015), Sistem Pelayanan Administrasi Kependudukan Desa Candigatak Berbasis Web, Jurnal IT CIDA Vol 1 No. 1 Desember 2015, 2477-8133

Agus Yhoni., dan Mahendra Setya (2015), Perancangan Sistem Informasi
Penduduk Pada Kantor Desa Kebonsari, IJNS, Vol. 4 No. 2 April $2015,2302-5700$

Ali Ibrahim, Ahmad Rifai dan Lina Oktarina (2016), Rancang Bangun Plikasi Pencatatan Data Penduduk Kelurahan Pahlawan Berbasis Web, Jurnal Sistem Informasi (JSI), VOL. 8, NO. 1, April 2016, 2085-1588

Muhammad Agus Suripto, Ramadian Agus Triyono (2014), Pembangunan Sistem Informasi Akta Kelahiran Dinas Kependudukan Dan Pencatatan Sipil Sragen, IJNS, Vol 3, No 3, Juli 2014, 2302-5700

Hutahaean, Jeperson, Konsep Sistem Informasi., Ed.1, Cet.1, Yogyakarta: Deepublish, Agustus-2014.

Hakim, Lukmanul. 2010. Membangun Web Berbasis PHP dengan Framework Codeigniter. Yogyakarta: Lokomedia

Mulyadi. 2014. Sistem Akuntansi. Cetakan Keempat. Jakarta: Salemba Empat.

Badan Pusat Statistik, Kependudukan, Diakses 30 Bulan Juli Tahun 2019. https://www.bps.go.id/subject/12/kepe ndudukan.html

Mulyadi Subri. 2003. Ekonomi Sumber Daya Manusia dalam Perspektif Pembangunan. PT Raja Grafindo Persada. Jakarta

Bekti, Bintu Humairah. 2015. Mahir Membuat Website dengan Adobe Dreamweaver CS6, CSS dan JQuery. Yogyakarta: ANDI

Wikipedia Ensiklopedia Bebas, Kelurahan diakses Tanggal 29 Bulan Juli Tahun 2019.

https://id.wikipedia.org/wiki/Keluraha $\mathrm{n}$ 